\title{
Screening Senyawa Pandu Inhibitor Endositosis dengan Metode Molecular Modelling
}

\author{
Dian Herlinda Octorina Howan
}

Ilmu Kimia FMIPA, Universitas Negeri Manado, Tondano, 95619, Indonesia

\begin{tabular}{l} 
I N F O A R T I KE L \\
\hline Diterima 09 April 2018 \\
Disetujui 30 April 2018 \\
\hline Key word: \\
inhibitor, \\
endocytosis, \\
molecularmodeling \\
\hline Kata kunci: \\
inhibitor, \\
endositosis, \\
molecularmodeling
\end{tabular}

*e-mail:

dian_octorina@yahoo.com *Telp:

\begin{abstract}
A B S TR A C T
The purpose of this research is to search for compound inhibitor endocytosis by using Molecular Modeling program. Screening is performed on approximately 800,000 compounds derived from several commercial companies. From the results of virtual screening obtained 320 hits, and of this number only 175 compounds that can be obtained to test its biological activity. Biological tests showed that there were 7 compounds with moderate endocytosis inhibition capability $\left(I_{50}=50-170 \mu \mathrm{M}\right)$ to good inhibition $\left(I C_{50}<50 \mu \mathrm{M}\right)$. The compounds are: compound $1\left(I_{50}=42 \pm 4 \mu \mathrm{M}\right)$, compound $2\left(I_{50}=83 \pm 8 \mu \mathrm{M}\right)$, compound $3($ IC50 $=135 \pm 58 \mu \mathrm{M})$, compound 4 $\left(I C_{50}=151 \pm 18 \mu \mathrm{M}\right)$ compound $5($ IC $50=144 \pm 18 \mu \mathrm{M})$, compound $6\left(I_{50}=13 \pm 4\right.$ $\mu \mathrm{M})$, and compound $7\left(I_{50} \sim 170 \mu \mathrm{M}\right)$.
\end{abstract}

\section{A B S TR A K}

Tujuan dari penelitian ini adalah untuk mencari senyawa pandu inhibitor endositosis dengan menggunakan program Molecular Modelling. Screening dilakukan te rha dap kurang lebih 800.000 senyawa yang berasal da ri beberapa perusahaan komersil. Dari hasil virtual screening didapatkan 320 hits, dan dari jumlah ini hanya 175 senyawa yang bisa didapatkan untuk diuji keaktifan biologisnya. Ujibiologis menunjukkan terdapat 7 senyawa dengan kemampuan inhibisi endositosis yang moderat $\left(\mathrm{IC}_{50}=50-170 \mu \mathrm{M}\right)$ sampai kemampuan inhibisi yang baik $\left(\mathrm{IC}_{50}<50 \mu \mathrm{M}\right)$. Senyawa-senyawa tersebut a dalah : senyawa $1\left(\mathrm{IC}_{50}=42 \pm 4 \mu \mathrm{M}\right)$, senyawa $2\left(\mathrm{IC}_{50}=83 \pm 8 \mu \mathrm{M}\right)$, senyawa $3\left(\mathrm{IC}_{50}=135 \pm 58 \mu \mathrm{M}\right)$, senyawa $4\left(\mathrm{IC}_{50}=151 \pm 18 \mu \mathrm{M}\right)$, senyawa $5\left(\mathrm{IC}_{50}=144\right.$ $\pm 18 \mu \mathrm{M})$, senyawa $6\left(\mathrm{IC}_{50}=13 \pm 4 \mu \mathrm{M}\right)$, dan senyawa $7\left(\mathrm{IC}_{50} \sim 170 \mu \mathrm{M}\right)$.

\section{Pendahuluan}

Endositosis adalah proses yang terjadi pada semua sel eukariotik dengan beberapa mekanisme yang dapat dibagi dalam dua tipe, yaitu Pagositosis, dan Pinositosis. Pagositosis dapat terjadi pada sel mamalia tertentu, sementara Pinositosis dapat terjadi pada semua tipe sel, dimana proses ini diatur oleh signal intraselular dan ekstraselular [1]. Pagositosis adalah proses yang terjadi saat sel menyerap partikel berukuran besar, sementara Pinositosis adalah proses penyerapan cairan, zat terlarut dan molekul kecil oleh sel. Selanjutnya Pinositosis dapat dibagi lagi menjadi dua mekanisme yang berbeda, yaitu clathrin mediated endocytosis dan clathrin-independent endocytosis (CME).

Sebagian besar Pinositosis sel eukariotik terjadi melalui mekanisme CME dan melibatkan serangkaian protein clathrin dan berbagai protein penerima pada sisi sitoplasma dari vesikel. CME memiliki dua jalur mekanisme, yaitu receptor mediated endocytosis dan synaptic vesicle endocytosis.

Proses CME biasanya diawali dari pengikatan sejumlah zat terlarut pada reseptor dengan afinitas tinggi pada membrane plasma, yang dikenal sebagai receptor mediated endocytosis (RME). RME terjadi akibat pembentukan clathrin-coated vesicles (CCV) yang 
melibatkan pembentukan mantel pelindung diikuti oleh pengikatan reseptor, penutupan lubang mantel, dan diakhiri dengan pembentukan vesikel (Gambar 1). Ada tiga set protein yang dibutuhkan untuk CCV, yaitu clathrin, protein adaptor, dan protein sekunder [2].

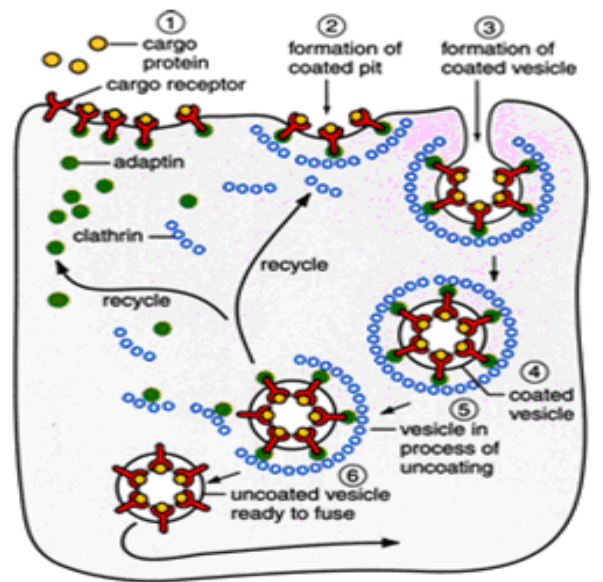

Gambar 1. Receptor-Mediated Endocytosis

Clathrin memiliki strukur dengan tiga kaki, yang dikenal dengan triskeleton, yang terdiri dari tiga rantai clathrin yang besar (192 $\mathrm{kDa})$, dan tiga rantai clathrin yang ringan (30 $\mathrm{kDa}$ ). Clathrin adalah protein utama dalam CCV karena dapat membentuk suatu lubang seperti mantel yang menyelimuti membrane vesikel internal [3]. Protein adaptor (AP) pertama kali diidentifikasi sebagai faktor yang menyebabkan pembentukan struktur mantel dari clathrin trimer yang telah dimurnikan. AP memediasi pembentukan clathrin di suatu titik pada membrane, dan merangsang pembentukan struktur clathrin pada saat pengikatan. Terdapat dua tipe AP yang berbeda struktur; monomer dan spesifik dijumpai pada sel otak yaitu AP180[4], dan tetramerik kompleks AP-1 dan AP-2 [1]. Grup protein yang ketiga dalam pembentukan vesikel adalah protein sekunder yang memiliki fungsi sebagai penghubung dalam pembentukan struktur clahtrin, pengaturan ulang struktur clahtrin, dan menjalankan proses pembentukan vesikel. Enzim dinamin termasuk dalam grup ini bersama dengan Eps-15, epsin, sinaptojanin, ampifisin, endofilins, dan Dab-2 [5].

Salah satu dari protein sekunder, yaitu dinamin telah diteliti secara mendalam. Awalnya dinamin dikaitkan dengan $\mathrm{CME}$ melalui penelitian tentang identifikasi mutant yang dipengaruhi oleh suhu pada lalat buah Drosophila melanongaster, dimana lalat dewasa yang memiliki mutasi pada gen shibire berlaku normal pada temperature $<21^{\circ} \mathrm{C}$, tetapi saat temperature dinaikkan diatas $28^{\circ} \mathrm{C}$, lalat ini mengalami kelumpuhan sementara. Hal ini disebabkan karena penghambatan dalam recycle vesikel sinapsis dan dari analisis morfologi ditemukan bahwa terdapat pembentukan mantel di sekitar tempat endositosis. Hasil sekuens dari mutasi shibire menunjukkan kehadiran homolog dari dinamin, yang kemudian disimpulkan bahwa dinamin berperan dalam proses endositosis [6].

Synaptic vesicle endocytosis (SVE) merupakan tipe CME yang khusus dimana model ini tidak bergantung pada reseptor dan hanya ditemukan di jaringan neuron [7]. Komponen protein yang terlibat dalam RME juga ditemukan dalam SVE, tetapi dengan beberapa perbedaan pada pasangan neuron dan isoformnya. Level dinamin 1 dalam sel neuron lebih besar daripada dinamin 2, walaupun kedua bentukisoform ini ditemukan dalam sel neuron. Karena SVE merupakan bentuk khusus dari RME, maka proses SVE memiliki beberapa langkah tambahan, yaitu pelepasan clathrin-mediated synapsis vesikel, pembentukan mantel clathrin, dan penggabungan dengan endosome, pembagian menjadi vesikel sinapsis, dan pengisian dengan neurotransmitter. SVE dikontrol oleh defospin (Gambar 2). Tidak seperti sel non-neuron, SVE terjadi pada titik yang jauh dari sel tubuh, dan semua komponen harus dipindahkan ke terminal saraf [8].

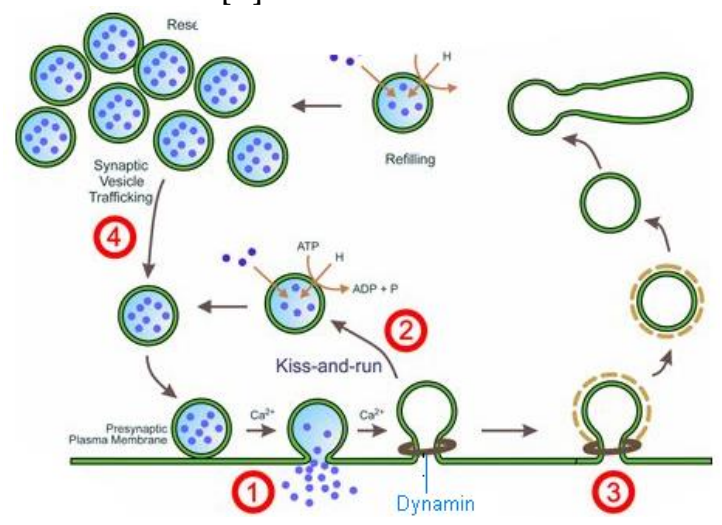

Gambar 2. Synaptic Vesicle Endocytosis

Endositosis memainkan peranan penting dalam berbagai kondisi patologis manusia. 
Kurang lebih ada 100 penyakit yang diketahui melibatkan endositosi dan intraselular trafficking [9, 10]. Dengan mengendalikan endositosis melalui penghambatan (inhibisi) dinamin, sangatlah berguna pada pengobatan kanker, bakteri, dan infeksi patogenis lainnya. Beberapa studi menunjukkan sejumlah penyakit yang berhubungan dengan dinamin, seperti penyakit Charcot-Marie-Tooth (CMT), Centronulear Myopathy (CNM) [11], dan virus Papilloma (HPV16 dan BPV1) yang merupakan agen etiologis pada kanker serviks dan anal, serta tumor dan penyakit pada hew an [12].

Beberapa penyakit degeneratif saraf juga dihubungkan dengan dinamin, diantaranya penyakit Alzheimer, penyakit Huntington, sindrom kaku pada manusia, dan penyakit Niemann-Pick tipe C [10]. Protein presinaptik $\alpha$-sinuklein dipercaya terlibat dalan penyakit Parkinson, dan Alzheimer. Keadaan patologis ini disebabkan karena endositosis $\alpha$-sinuklein sehingga inhibitor endositosis dapat berguna dalam perawatan penyakit yang berhubungan dengan $\alpha$-sinuklein. Endositosis juga berimplikasi dalam epilepsy $[13,14]$. Epilepsi merupakan suatu gejala kronis dari abnormalitas sel neuron, dan diklasifikasikan sebagai kelompok penyakit yang disebabkan oleh pergerakan (seizure) yang cepat dan spontan secara terus menerus dari sel saraf. Pada manusia, epilepsy adalah kondisi heterogen dimana dapat dibedakan penyebabnya secara genetik atau karena faktor lainnya. Kejang pada epilepsy disebabkan oleh transmisi sinapsi yang terlalu cepat. Tranmisi sinapsi merupakan pelepasan neurotransmitter oleh eksositosis dari tempat penyimpanannya, vesikel sinapsi (SVs), dalam terminal saraf presinapsis. Proses ini dikendalikan oleh sifat elektris dari neuron dan transmisi kimia sepanjang sinaps. Terminal saraf memiliki struktur elektris yang dapat mempertahankan potensial membrane yang bermuatan negative sehingga depolariasi dapat mengaktifkan saluran $\mathrm{Ca}^{2+}$ untuk merangsang eksositosis.

Sejumlah inhibitor dinamin telah ditemukan, diantaranya Dinasor yang ditemukan oleh Macia, yang dapat menghambat RME, Bis-T [15], miristil trimetilammoniumbromide, dan dinoles.
Berdasarkan uraian diatas, maka penulis tertarik untuk meneliti tentang screening senyawa pandu inhibitor endositosis menggunakan program molecular modeling. Hal ini dirasakan bermanfaat karena dapat menghemat waktu dan tenaga dalam mencari struktur senyawa potensial yang dapat dikembangkan menjadi senyawa obat (therapeutic) terhadap penyakit-penyakit yang disebabkan oleh endositosis, khususnya dinamin.

\section{Bahan dan Metode}

Penelitian ini dilakukan di Laboratorium Kimia University of Newcastle, dan Cell Signaling Unit, Children's Medical Research Institute, The University of Sydney, Australia. Bahan utama penelitian yang digunakan adalah Database senyawa kimia, Enzim Dinamin 1, Liposom fosfatidilserin, Larutan $\mathrm{HCl}$, Larutan $\mathrm{NaCl}$, Tween 80, Leupeptin, PMSF, GTP, Larutan EDTA 0,5 M dan Larutan Malachite Green. Alat yang digunakan adalah Software ICM flexible ligand-grid receptor algorithm, Software Chem Draw, 1 set computer, Koneksi Internet, Perangkat alat gelas dan Eppendorf Thermomixer, Spektrofotometer mikroplat, Program Graphpad Prism 5

Langkah pertama dalam pembuatan database senyaw a adalah mengumpulkan data senyawa-senyawa kimia yang diproduksi secara komersial (ChemBridge dan ChemDiv). Data senyawa yang didapat selanjutnya digambarkan struktur kimianya dengan software Chem Draw, selanjutnya dibuat matriks untuk menyusun struktur senyawasenyawa tersebut. Database senyawa ini kemudian akan digunakan dalam pemodelan molekul.

Senyawa-senyawa yang ada dalam database kemudian didocking ke model homolog domain GTPase dinamin 1 manusia (hDyn1-2 dan hDyn1-7) dengan menggunakan software ICM flexible ligand-gried receptor algorithm. Dari hasil screening virtual ini, akan didapatkan senyawa-senyawa yang memiliki potensial inhibisi terhadap dinamin. Selanjutny a senyawa-senyawa ini diuji aktifitas biologis terhadap dinamin. Senyawa dengan 
nilai $\mathrm{IC}_{50}<200 \mu \mathrm{M}$ dapat digunakan sebagai senyaw a pandu untuk pengembangan inhibitor dinamin.

Uji aktifitas inhibitor Dinamin menggunakan metode Malachite Green, karena metode ini dapat mendeteksi perubahan warna pada ortofosfat. Metode ini berdasar pada pembentukan suatu kompleks fosfomolibdat pada $\mathrm{pH}$ rendah dalam zat warna basa, yang menyebabkan perubahan warna. Prosedur kerja didasarkan pada stimulasi enzim dinamin 1 yang diisolasi dan dimurnikan dari otak sapi dengan menggunakan liposom fosfatidilserin (FS). Enzim Dinamin 1 yang telah dimurnikan $(20 \mathrm{nM})$ (dilarutkan dalam $6 \mathrm{nM} \mathrm{HCl}, 20 \mathrm{nM}$ $\mathrm{NaCl}, 0,01 \%$ Tween 80, pH 7,4) diinkubasi dalam larutan uji GTPase $(5 \mathrm{mM} \mathrm{HCl}, 10 \mathrm{nM}$ $\mathrm{NaCl}, 2 \mathrm{mM} \mathrm{Mg}{ }^{2+}, 0,05 \%$ Tween 80, pH 7,4, 1 $\mathrm{mg} / \mathrm{mL}$ leupeptin dan $0,1 \mathrm{mM}$ PMSF) yang dicampur dengan GTP 0,2 mM. Selanjutnya larutan uji dicampurkan ke dalam larutan ini dan didiamkan selama 30 menit pada suhu $37^{\circ} \mathrm{C}$. Volume larutan akhir sebanyak $150 \mathrm{~mL}$ kemudian diletakkan dalam plat uji sebanyak 96 plat. Plat uji kemudian diinkubasi dalam Eppendorf Thermomixer, dengan putaran 600 rpm. Aktifitas GTPase dinamin 1 distimulasi dengan penambahan $4 \mu \mathrm{g} / \mathrm{mL}$ liposom FS. Reaksi kemudian dihentikan dengan penambahan $10 \mathrm{~mL}$ EDTA $0,5 \mathrm{M}$ pH 8.0 dan sampel distabilkan selama beberapa jam pada suhu kamar. Ke masing-masing plat ditambahkan $40 \mu$ larutan Malachite Green (2\% $\mathrm{m} / \mathrm{v}$ mmonium molibdat tetrahidrat, $0,15 \% \mathrm{~m} / \mathrm{v}$ malachite hijau dan $4 \mathrm{M} \mathrm{HCl}$; larutan disaring pada penyaring dengan ukuran $0,45 \mu \mathrm{m}$ dan disimpan dalam ruang gelap selama kurang lebih 2 bulan pada suhu kamar), dan dibiarkan selama kurang lebih 5 menit untuk melihat perubahan $w$ arnayang terjadi. Larutan ini akan stabil sampai 2 jam. Absorbans dari sampel dalam masing-masing plat diukur dengan menggunakan spektrofotometer mikroplat pada panjang gelombang $650 \mathrm{~nm}$. Pelepasan fosfat dihitung dengan membandingkan kurva standar dari natrium dihidrogen ortofosfat monohidrat (dipanggang pada suhu $110^{\circ} \mathrm{C}$ selama semalam) yang digunakan dalam tiap percobaan. Untuk memplot data digunakan program GraphPad Prism 5, dan analisis kinetic enzim menggunakan regresi non-linier, Data
GTPase Dinamin 1 dilaporkan sebagai aktifitas basal yang dikurangi dari aktifitas FSterstimulasi.

\section{Hasil dan Pembahasan}

Dari matriks data senyawa dari dua katalog perusahaan farmasi, ChemBridge dan ChemDiv, didapat sekitar 800.000 senyawa. Senyawa-senyawa ini kemudian didocking ke dalam model homologi domain GTPase dinamin I. Screening data ini dilakukan terhadap dua varian model homologi yang dikembangkan oleh grup McCluskey, yaitu hDyn1-3 dan hDyn1-7 (Gambar 3 dan 4) menggunakan logaritma ligand-grid reseptor fleksible ICM, dan menghasilkan 320 hits. Kedua domain ini dipilih karena memiliki nilai ICM yang baik (Tabel 1).

Tabel 1 Representasi Model Homologi dan Nilai ICM untuk Interaksi dengan GDP dan GTP

\begin{tabular}{|l|c|c|}
\hline \multirow{2}{*}{ Model } & \multicolumn{2}{c|}{ Nilai ICM } \\
\cline { 2 - 3 } & GDP & GTP \\
\hline hDyn1-1 & $-60,87$ & $-29,75$ \\
\hline hDyn1-2 & $-64,85$ & $-39,95$ \\
\hline hDyn1-3 & $-75,55$ & $-79,13$ \\
\hline hDyn1-4 & $-67,60$ & $-68,76$ \\
\hline hDyn1-5 & $-69,08$ & $-73,39$ \\
\hline hDyn1-6 & $-65,32$ & $-49,17$ \\
\hline hDyn1-7 & $-71,51$ & $-79,87$ \\
\hline
\end{tabular}

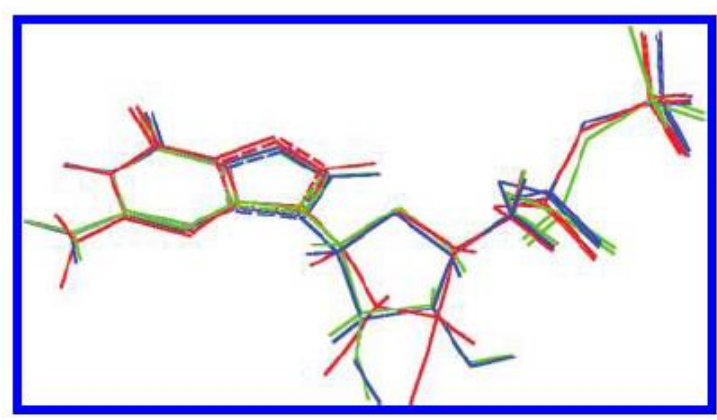

Gambar 3 Model pengikatan GDP menggunakan hDyn1-3 (merah) dan hDyn1-7 (hijau) relative terhadap konformasi dinamin. Struktur Kristal (Biru, PDB kode 1JWY) 


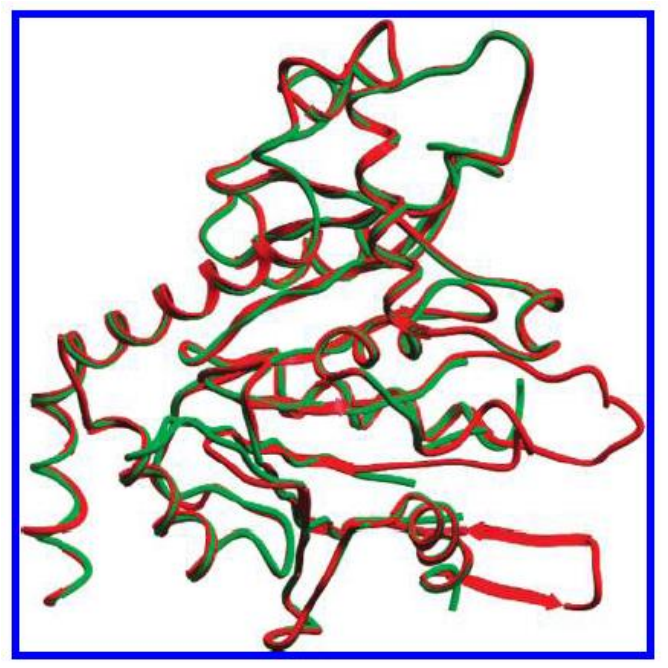

Gambar 4 Struktur Backbone model homologi hDyn1-3 dan hDyn1-7 (merah) (C ${ }^{\alpha}$ rmsd 1.09

Å) pada struktur kristal GTPase domain dinamin 1 dari tikus (hijau, PDB kode 2AKA)

Dari 320 senyawa ini, hanya 175 senyaw a yang masih bisa didapatkan kembali untuk diuji secara biologis. Dari uji biologis awal, 7 senyawa diketahui memiliki kemampuan menghambat dinamin secara moderat $\left(\mathrm{IC}_{50}=50-170 \mu \mathrm{M}\right)$, sampai memiliki kemampuan menghambat yang baik ( $\mathrm{IC}_{50}<50$ $\mu \mathrm{M})$ (Tabel 2). Salah satu senyawa yang aktif adalah senyawa 7 , yaitu senyawa turunan phthalimide (IC $50 \sim 170 \mu \mathrm{M}$ ).

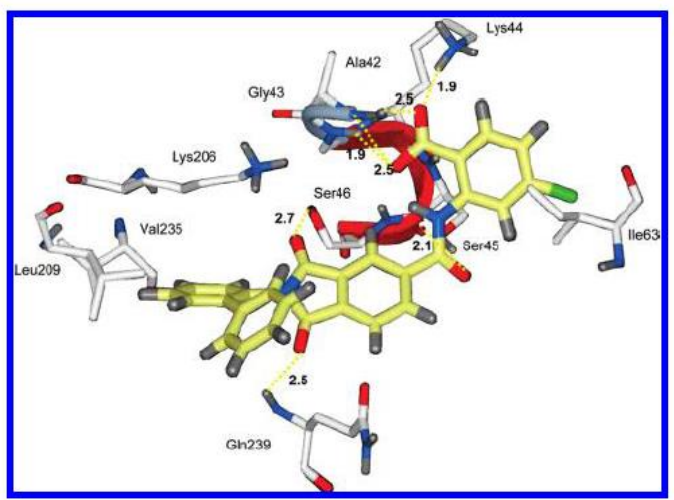

Gambar 5 Prediksi Pengikatan Senyawa 7 dalam Sisi Pengikatan hDyn1-3. Kode warna: oksigen, merah; nitrogen, biru; hydrogen, abuabu; klorin, hijau (hanya sisi pengikatan atom hydrogen polar yang diperlihatkan). Atom karbon ditunjukkan dalam warna putih (hDyn1-3) dan kuning (1). Ikatan hydrogen ditunjukkan lew at titik-titik garis kuning dengan jarak antar atom dalam $\AA$.
Tabel 2. Evaluasi biologis senyawa 1-7 yang diidentifikasi dari screening virtual sebagai inhibitor GTPase Dinamin I

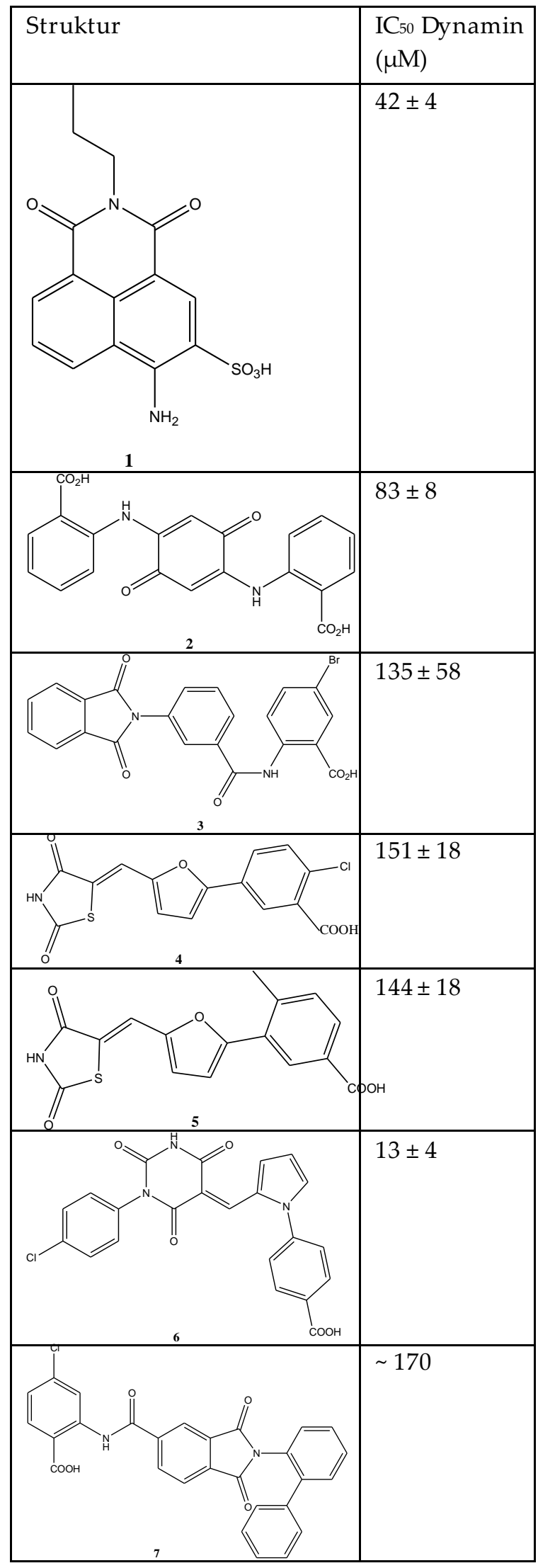


Senyawa 7 mengandung gugus Nimida bifenil dan asam 4-klorobenzoat, yang terhubung dengan phthalimide melalui ikatan amida. Hasil uji biologis untuk senyawa 7 menunjukkan senyawa ini sebagai inhibitor moderat terhadap dinamin dengan nilai IC 50 $170 \mu \mathrm{M}$, dan dari evaluasi tipe ikatan menunjukkan bahwa senyawa ini terikat dengan beberapa ikatan hydrogen, interaksi ionik dan van der Waals pada bagian aktif dari residu (Gambar 5).

Dari analisis struktur senyawa 7, menunjukkan bahw a senyaw a ini memiliki dua bagian yang dapat dieksplorasi untuk meningkatkan keaktifannya. Bagian yang pertama adalah pada gugus asam karboksilat, dan bagian yang kedua pada gugus imida. Untuk dapat mengeksplorasi dua bagian ini, perlu diadakan sintesis homolog senyawa terhadap gugus 1-amido-2-asam benzoate, dan sintesis homolog mengalterasi biaril.

\section{Kesimpulan}

Berdasarkan hasil screening dan uji aktifitas, dapat disimpulkan bahwa screening senyawa pandu menggunakan program molecular modelling dapat menghasilkan struktur senyawa pandu yang memiliki nilai inhibisi yang baik terhadap dinamin. Hasil screening menunjukkan bahwa keberadaan gugus fungsi yang kaya akan electron bebas, seperti gugus asam karboksilat, serta senyawa yang mengandung gugus yang dapat membentuk ikatan hydrogen seperti gugus hidroksi, dapat menjadi kandidat senyawa pandu yang baik untuk inhibisi dinamin, khususnya pada GTPase domain. Untuk penelitian selanjutnya dapat dilakukan pengembangan seri analog dari masing-masing senyawa pandu yang didapat dari hasil screening ini untuk dapat meningkatkan keaktifan biologis dari senyawa tersebut terhadap endositosis.

\section{Daftar Pustaka}

1. Conner, S. D.; Schmid, S. L., Differential requirements for AP-2 in clathrinmediated endocytosis. The Journal of cell biology 2003, 162, (5), 773-780.

2. McMahon, H. T., Endocytosis: an assembly protein for clathrin cages. Current biology 1999, 9, (9), R332-R335.

3. Kirchhausen, T.; Harrison, S. C., Protein organization in clathrin trimers. Cell 1981, 23, (3), 755-761.

4. Murphy, J.; Pleasure, I.; Puszkin, S.; Prasad, K.; Keen, J., Clathrin assembly protein AP-3. The identity of the $155 \mathrm{~K}$ protein, AP 180, and NP185 and demonstration of a clathrin binding domain. Journal of Biological Chemistry 1991, 266, (7), 4401-4408.

5. Mousavi, S. A.; Malerød, L.; Trond, B.; Kjeken, R., Clathrin-dependent endocytosis. Biochemical Journal 2004,377, (1), 1-16.

6. Chen, M. S.; Obar, R. A.; Schroeder, C. C.; Austin, T. W.; Poodry, C. A.; Wadsw orth, S. C.; Vallee, R. B., Multiple forms of dynamin are encoded by shibire, a Drosophila gene involved in endocy tosis. Nature 1991, 351, (6327), 583.

7. Liu, J.-P.; Robinson, P. J., Dynamin and endocytosis. Endocrine reviews 1995, 16, (5), 590-607.

8. Ferguson, K. M.; Lemmon, M. A.; Schlessinger, J.; Sigler, P. B., Crystal structure at $2.2 \AA$ resolution of the pleckstrin homology domain from human dynamin. Cell 1994, 79, (2), 199209.

9. Aridor, M.; Hannan, L. A., Traffic jam: a compendium of human diseases that affect intracellular transport processes. Traffic 2000, 1, (11), 836-851.

10. Aridor, M.; Hannan, L. A., Traffic jams II: an update of diseases of intracellular transport. Traffic 2002, 3, (11), 781-790.

11. Bitoun, M.; Maugenre, S.; Jeannet, P.-Y.; Lacene, E.; Ferrer, X.; Laforêt, P.; Martin, J.-J.; Laporte, J.; Lochmüller, H.; Beggs, A. H., Mutations in dynamin 2 cause dominant centronuclear myopathy. Nature genetics 2005, 37, (11), 1207.

12. Abban, C. A.; Bradbury, N. A.; Meneses, P. I., HPV16 and BPV1 infection can be blocked by the dynamin inhibitor dynasore. American journal of therapeutics 2008, 15, (4), 304.

13. Di Paolo, G.; Sankaranarayanan, S.; Wenk, M. R.; Daniell, L.; Perucco, E.; Caldarone, B. J.; Flavell, R.; Picciotto, M. R.; Ryan, T. A.; Cremona, O., Decreased synaptic vesicle recycling efficiency and cognitive deficits in amphiphysin 1 knockout mice. Neuron 2002, 33, (5), 789804.

14. Crow der, K. M.; Gunther, J. M.; Jones, T. 
A.; Hale, B. D.; Zhang, H. Z.; Peterson, M. R.; Scheller, R. H.; Chavkin, C.; Bajjalieh, S. M., Abnormal neurotransmission in mice lacking synaptic vesicle protein $2 \mathrm{~A}$ (SV2A). Proceedings of the National Academy of Sciences 1999, 96, (26), 1526815273.

15. Hill, T.; Odell, L. R.; Edwards, J. K.; Graham,M. E.; McGeachie, A. B.; Rusak, J.; Quan, A.; Abagyan, R.; Scott, J. L.; Robinson, P. J., Small molecule inhibitors of dynamin I GTPase activity: development of dimeric tyrphostins. Journal of medicinal chemistry 2005, 48,(24), 7781-7788. 